\title{
Characterization of Native Plants with Phytoremediation Potential in Ancash - Peru Respect to their Capacity of Propagation and Accumulation of Heavy Metals
}

\author{
Jose Chang Kee ${ }^{1}$, María Gonzales ${ }^{1}$, Olga Ponce ${ }^{1}$, Lorena Ramirez ${ }^{1}$, Carlos Flores ${ }^{1}$, Vladimir León ${ }^{2}$, \\ Adelia Torres $^{2}$, Melissa Corpus ${ }^{2}$, Raúl Loayza ${ }^{1}$ \\ ${ }^{1}$ Universidad Peruana Cayetano Heredia \\ Av. Honorio Delgado 430 SMP, Lima, Perú \\ jose.chang.kee@upch.pe; raul.loayza@upch.pe \\ ${ }^{2}$ Universidad Nacional Santiago Antúnez de Mayolo \\ Centenario 325, Huaraz, Perú
}

\section{Extended Abstract}

The toxicity of heavy metals produced by mine tailings attempts against health in all the countries that face this problem [1]. In Peru, the Ancash department is a region which possesses more than 1251 reported high risks mine tailings until 2015, some of them are: "Alianza" (680 $000 \mathrm{~m} 2)$, "Huancapetî" (400 $000 \mathrm{~m} 2)$, "La Romina" (260 $000 \mathrm{~m} 2)$, "Pasto Bueno" (85 $000 \mathrm{~m} 2)$, "California y Tungsteno" (60 $000 \mathrm{~m} 2)$, and "Mesapata" (54 $500 \mathrm{~m} 2)$ [2,3,4]. As a response, phytoremediation emerges as an eco-friendly and cost-efficient method suitable to treat these problems, in a process in which plants are able to capture, stock or degrade heavy metals [5]. Previously, up until 12 native genus with phytoremediation potential coming from contaminated areas of Recuay, Cátac and Huancapetí (Ancash) were identified $[6,7,8]$. With the purpose of continuing with this study, we proposed the evaluation the propagation potential and the characterization of the hyperaccumulation capacity of heavy metals in these plants. The study was carried out in a greenhouse located at $3433 \mathrm{msmm}$ to simulate their natural environment. Plants were grown either through seeds or cuttings according to the species, and their size was measured every 15 days during three months. After this time, plants with the best germination rate were selected to go through the heavy metal exposure treatment. In this experiment each plant genus was grown in either of three groups: in peat (control group), in soil belonging to mine tailing (first treatment) and in peat in which it was added solutions of different heavy metals (second treatment). After three months of treatment, heavy metal concentration in soils, roots and shoots were measured, as well as dry weight of the later two. In order to analyze the data, we obtained a ratio of the accumulation percentage between the end and the beginning of the treatment in roots and shoots for each plant. The results showed that the absorption efficiency varies depending on the evaluated species, as well as it varies between roots and shoots. We have 4 heavy metals of high interest, Aluminium, Cadmium, Copper and Lead. In the case of the mine tailings treatment, Werneria was the genus that accumulated the most amount of aluminium in its shoots and roots (20 times and 4 times more than the control, respectively) followed by Senecio and Juncus which accumulated approximately 12 times more in its shoots compared to control. Calamagrostis, Festuca, Juncus, Senecio, Stipa and Werneria showed an accumulation of cadmium up until 9 times in shoots. Calamagrostis, Juncus, Pennisetum, Senecio and Stipa accumulated lead up until 30 times more in shoots. In case peat with heavy metals added, there were no differences of aluminium accumulation. Calamagrostis, Festuca, Juncus, Senecio, Stipa and Werneria showed an accumulation average of 15 times more of cadmium in shoots compared to the control. Lead was hyperaccumulated by Calamagrostis, Juncus, Pennisetum, Senecio and Stipa, with an average of 100 times more than the control group in shoots. Finally, Calamagrostis, Festuca, Senecio and Werneria accumulated the greater amount of copper with an average of 10 times more in comparison to the control group in roots, independently of the treatment. Aside from that, out of all the species evaluated, only Penisetum, Juncus, Festuca and Senecio generated a high amount of biomass in either their roots or shoots, another requirement to make them good candidates for phytoremediation. By crossing the metal biomass information we conclude that Juncus, Festuca and Penisetum emerge as the plants with the highest phytoremediation potential for the Ancash department in Recuay, Cátac and Huancapetí. 


\section{References}

[1] A. Bhargava, F. Carmona, M. Bhargava, S. Srivastava, "Approaches for enhanced phytoextraction of heavy metals," Journal of Environmental Management, vol. 105, pp. 103-120, 2012.

[2] DESA (Dirección Ejecutiva de Salud Ambiental), Grupo Técnico Control y Recuperación de la Calidad de las Aguas del río Santa. Comisión Ambiental Regional Sierra Ancash - CAR, Ancash, 2002.

[3] DESA (Dirección Ejecutiva de Salud Ambiental), Vertimientos y pasivos ambientales en la cuenca del río Santa, 2002.

[4] Ministerio de energía y minas (MINEM), 2016. Inventory of mining liabilities, [Online]. Available: http://www.minem.gob.pe/_legislacionM.php?idSector=1\&idLegislacion=10991

[5] S. Susarla, "Phytoremediation: an ecological solution to organic chemical contamination," J. Ecol Eng, vol. 18, no 5, pp. 647-658, 2002.

[6] M. Bobadilla, "A phytoremediation approach using Calamagrostis ligulata and Juncus imbricatus in Andean wetlands of Peru," J. Environ Monit Assess., vol. 185, no 1, pp. 323-334, 2013.

[7] E. J. Palomino, "Sistemas de humedales para la Biorremediación de drenajes ácidos de mina o roca en Anchash Perú," "Wetlands systems for bioremediation of mine acid drains or rock in Quilcayhuanca, Ancash- PERU," Ph.D. dissertation, Dept. Environ. Sci., National Trujillo Univ., Lima, Peru.

[8] D. Nañez, "Estudio y selección de especies vegetales con potencial biorremediador en drenajes ácidos de roca y relaves minerales de la cuenca del río Santa (Áncash, Perú)," Bachelor dissertation, Dept. Biochemistry, and Molecular Biology., Cayetano Heredia Univ., Lima-Perú. 